\title{
Advising Faculty on Law Journal Publication Agreements
}

\author{
Benjamin J. Keele, Reference Librarian \\ William \& Mary Law Library
}

One of the primary areas of service for academic librarians is faculty support, and one of faculty's primary goals is to publish law journal articles. Librarians provide a lot of assistance in the pre-submission phase of an article's development - crafting searches, retrieving sources, and compiling statistics. We also help journal staff with cite-checking after an article has been submitted and accepted. An additional service librarians can offer faculty is reviewing journal publication agreements when articles are accepted.

\section{Why advise faculty on publication agreements?}

Very few people enjoy dealing with copyright agreements, but agreements last for a long time and, once signed, are very difficult to change. Thus, it is very important for faculty to think about what rights they wish to retain and ensure that the agreement reflects those preferences before signing. Suppose a professor publishes an article without carefully reviewing the publication agreement. A couple years later, she decides to republish the article in a collection of essays or make copies for a class course pack. She may then discover that the journal's copyright policies require special permission or fees for such uses, a development that may require more time and energy to resolve than would have been needed to negotiate a more flexible agreement.

I offer to review journal publication agreements for faculty for whom I am the liaison librarian. I do not offer to review contracts for monographs because books are made in a more complicated economic market than law journal articles. For a study on publication agreements, I examined a number of different journals' agreements, so I thought I had a reasonable feel for which provisions were standard and which were outliers.

So far I've reviewed two agreements and recommended small changes for each. For the first agree- ment, I suggested making explicit that the author can post drafts and the published paper in SSRN, a standard means of distributing legal scholarship. For the second agreement, I suggested removing a rather unusual clause that asked the author to waive all moral rights in the article. This provision was strange for two reasons. First, moral rights are more a creation of European than U.S. law, and second, one of the moral rights is the right to be attributed as the author, which is one of the most desirable rights for scholars.

Providing advice on copyright agreements is not one of most traditional reference tasks, but I think it is a natural extension of librarians' expertise in two ways. First, academic librarians have experience with most parts of the life cycle of an article. They assist with research for articles and then collect and retrieve published articles. Librarians also tend to know the many avenues for distributing articles and thus the many choices faculty can make about using their work, if they retain the necessary rights. Second, patrons look to librarians for guidance on using information, which often includes some knowledge of copyright and its effect on scholarship.

\section{How do we provide this advice?}

One need not be a copyright expert to effectively review publication agreements for faculty. A basic grasp of copyright can be obtained from helpful websites or books on copyright and academic publishing (I list a few useful sources at the end of this article). One also needs to review a number of different agreements to develop familiarity with the issues most agreements cover. A precious few law journals make their agreements 


\section{Law Journal Publication Agreements, Cont'd}

\section{(Continued from page 3 )}

publicly available. Review those and ask the journals at your institution for their agreements.

Journals tend to copy language from other agreements, and a model agreement issued by the American Association of Law Schools in 1998 has been adopted by many journals. This means most agreements cover the same issues and differ in only a few details. Those details, such as an embargo on posting the article on a personal or institutional website, may be important to faculty. Once you've seen a few agreements and know which issues are most important, you will notice when an agreement contains a provision that is unusual and warrants further discussion with the journal.

\section{Crucial Issues}

Journals need certain rights to publish articles. Many student-edited journals are heavily subsidized by their law schools, but to some extent journals need to maintain adequate funding to operate. The goal should be to grant journals the rights needed to operate while giving the author as much flexibility as possible for future use of their works. Much of the language in any law journal agreement will be noncontroversial. For example, a journal is right to ask an author to warrant that her article is original and hasn't been published in another journal, and an author should have no trouble agreeing to that. Language authorizing the journal to load the article in databases like Westlaw, Lexis, and Hein is also likely to be acceptable, if not expected. Some provisions, however, are worth looking over and negotiating if needed.

While journals will likely present the agreement as standard procedure, a number of editors have indicated to me that they are willing to modify the agreement at author request. Authors may be concerned about the journal revoking its offer, but once editors have invested time and energy in selecting the article, it will generally be less work to reach agreement on the contract language than to rescind the offer and revisit the pile of submissions. Everyone has limits, of course, but professional and reasonable contract negotiations are unlikely to damage an author's relationship with the journal. Some institutions have prepared contract addenda that the author can simply attach to the signed agreement. This is a possible solution, but editors might feel they are losing more control (and thus be more reluctant to agree) than if they altered the journal's agreement.

Here are the issues I would be sure to check for in a publication agreement. My goal when reviewing an agreement is to help the author keep whatever rights she may need to use her work effectively in the future, while also giving the journal sufficient rights to operate.

\section{Transfer, Exclusive License, or Non-exclusive License}

The first item to look for in an agreement is the language covering copyright transfer or license. Given that most academic law journals are non-profit, educational operations, there is virtually no need for a journal to acquire full copyright in an article, and certainly not on a work-for-hire basis (such a designation would make the journal the legal author of the article). The agreement can be written to authorize any form of distribution a journal may wish to make without taking copyright from the author. The words "assign and transfer copyright" would be an issue $I$ would raise with the author. Many law journals ask for an exclusive or non-exclusive license. With an exclusive license, the author would not be able to republish the article elsewhere without permission. Some journals prefer exclusive licenses to help protect their subscription and database revenue. This seems acceptable as long as the 


\section{Law Journal Publication Agreements, Cont'd}

(Continued from page 4)

exclusive license becomes non-exclusive after a certain time. Exclusive licenses I have seen typically run six months to one year. An exclusive license lasting over three years would be unusual.

\section{Self-posting}

Next I would check to see if the agreement, regardless of type of transfer or license, permits the author to post drafts or the published article on personal or institutional websites. Some agreements will only permit posting to SSRN. This seems overly restrictive, especially since law schools are beginning to develop institutional repositories for faculty work and many authors have their own professional websites. If it is not in the agreement, I recommend asking to explicitly retain the right to post drafts and the published copy on websites under the author's or author's institution's control. Of course, the journal should be credited with first publication and will distribute the article in print, on its own website, and through databases.

Some journals impose embargoes on posting articles, again to protect subscriptions. These can be reasonable, but I would try to negotiate any embargo longer than one year. Even a one-year embargo might unduly limit the online attention the article receives. Unlimited posting of drafts and a six-month embargo on posting the published version strikes me as a fair compromise.

\section{Permissions to Third Parties}

Be sure to check for what uses the journal wishes to control permissions or charge fees. Some journals give advance, blanket permission for classroom copying. Journals may want power to decide whether to grant a request, or they may simply forward the request to the author for decision. Posting copies online might be allowed, but republishing the article in a book may require permission from the journal. Here it is helpful to know some of the author's preferences and future plans. Some authors may want maximum control over their work and thus prefer that the journal run all reprint requests by them. Others may not relish the prospect of dealing with permissions paperwork years after the article has been published.

\section{Journal Commitments}

I also check for some basic commitments from the journals. The author should be attributed in all copies and republications (as the author should credit the journal as the venue of first publication). The article should not be published unless it is in mutually acceptable form. The author should at least receive a digital copy of the published version, if not free paper copies. If these provisions are not present, I would suggest requesting them.

This is not to suggest that journal editors would act in bad faith. I think most editors seek to treat authors professionally, but in an unfortunate conflict, the publication agreement will be the document governing their relationship. Editors and authors should trust each other to fulfill their responsibilities, and writing out those responsibilities will help ensure everyone knows what is expected.

\section{Conclusion}

When I began paying more attention to publication agreements, I thought law professors would carefully examine and negotiate the agreements. In my experience, however, most professors treat agreements like credit card agreements or website privacy policies. Like the rest of us, they often agree to the language that is presented to them and do not think of it again until a problem arises. Publishing with a journal, however, is a much more permanent matter; one can cancel a credit card or boycott a website, but it would be quite a chore to withdraw an article during production or worse, after publication.

(Continued on page 12) 


\section{Law Journal Publication Agreements, Cont'd}

(Continued from page 11)

Librarians can help faculty by familiarizing themselves with basic copyright law and various agreements and offering informed review of journal contracts. This service will support informed faculty publishing, encourage access to scholarship (I am assuming most faculty very much want their work to be read), and encourage journal editors to adopt author-friendly agreements.

\section{Useful Resources}

\section{On Author Rights}

Bailey, Jr., Charles W., Author's Rights, Tout de Suite (2008), available at http://digitalscholarship.org/ts/authorrights.pdf.

Columbia University, KeepYourCopyrights, http:// www.keepyourcopyrights.org/ (last accessed Jan. 10, 2012).

Scholarly Publishing and Academic Resources Coalition, Author Rights, http://www.arl.org/sparc/ author/ (last accessed Jan. 10, 2012).

\section{On Law Journal Publication Agreements}

Keele, Benjamin J., "Copyright Provisions in Law Journal Publication Agreements," Law Library Journal 102(2): 269 (2010), available at http://aallnet.org/ main-menu/Publications/llj/LLJ-Archives/Vol-102/ publljv102n02/2010-15.pdf.

Keele, Benjamin J., “Copyright and Author Agreements for Open Access Law Journals," presented at the Implementing the Durham Statement Workshop (2010), available at http://scholarship.law.wm.edu/ libpubs/24/.

Widener, Michael N., "Safeguarding 'The Precious': Counsel on Law Journal Publication Agreements in Digital Times," John Marshall Journal of Computer and Information Law 28(2): 217 (2010), available at http://ssrn.com/abstract $=1674162$.

Sample Agreements

AALS Model: http://www.aals.org/deansmemos/9824.html.

Science Commons Model: $\underline{\text { http:// }}$

sciencecommons.org/projects/publishing/oalaw/ oalawpublication/.

Duke Law Journal: http://dlj.law.duke.edu/authoragreement/.

Michigan Law Review: http:// www.michiganlawreview.org/information/ submissions/licensing-agreement.

University of New Hampshire Law Review: http:// law.unh.edu/assets/pdf/unh-law-review-publishingagreement.pdf.

(C) 2012 by Benjamin J. Keele. This article is licensed under a Creative Commons Attribution 3.0 License, which permits the unrestricted use, distribution, and reproduction in any medium, provided the original author and source are credited. 